\title{
Integrated analytic hierarchy process and mixed integer programming for supplier selection in mold and dies industry
}

\author{
Agustinus Silalahi*, Ronald Sukwadi, Duhita Al Hayyu Pramesjwari, Chendrasari Wahyu \\ Oktavia, Christine Natalia \\ Department of Industrial Engineering, Faculty of Engineering, Atma Jaya Catholic University of Indonesia, Jl. Raya Cisauk Lapan, \\ Sampora, Tangerang, Banten 15345, Indonesia
}

\section{ARTICLE INFORMATION}

Article history:

Received: November 02, 2019

Revised: December 28, 2019

Accepted: December 31, 2019

\section{Keywords:}

Analytic Hierarchy Process

Mixed Integer Programming

Order Allocation

Supplier Selection

\section{A B S T R A C T}

PT. GMT has a mission to deliver the products to the customer on time and high-quality products to improve services. Sometimes, the delivery of products delays caused by the raw materials delays or didn't meet specifications. Selection optimal suppliers of raw materials are one of the solutions. There are two factors must be considered for the selection of suppliers, qualitative factors and quantitative factors. In this study, for qualitative factors, based on the criteria needed by PT GMT. This research produces three Linear Programming models, first: a qualitative objective function that will be maximized called the Total Value of Purchase (TVP). TVP is an integration of the Analytical Hierarchy Process (AHP) and Mix Integer Programming Integration. Second, the quantitative objective function for the procurement of raw materials, which is called the Total Cost of Purchase (TCP). The third is to optimize qualitative and quantitative simultaneously using the Goal Programming method. The selection of suppliers based on TVP the total value is 97.25, and the total of procurement cost is Rp. 36,914,000, based on TCP, the total value is 89.14 , and the total procurement cost is IDR $31,356,000$, while based on Goal Programming, the total value is 93.18, and the total of procurement cost is IDR 32,621,000. PT GMT has been able to determine the optimal supplier based on the policies set.

This is an open-access article under the CC-BY-NC-SA license.

*Corresponding Author

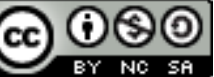

Agustinus Silalahi

E-mail: agust.silalahi@atmajaya.ac.id

\section{INTRODUCTION}

Competition in the industrial field today is very tight. The industry must make cost and time efficiency, until improving the quality of products and services to compete, including the manufacturing industry.
The manufacturing industry is an industry engaged in processing raw materials into finished goods that can be sold in the marketplace to obtain maximum profits [1]. Selection the right supplier has a significant impact on the performance of the manufacturing industry. Suppliers have a signifycant influence on a manufacturer's performance, 
through their contributions to cost reduction, new product design and enabling the constant improvement of quality [2].

Supplier selection is a critical activity in the manufacturing industry. The data shows that the manufacturing industry spends around $60 \%$ of product sales to buy raw materials for production [3]. Supplier selection is part of the company's strategic goals to achieve long-term goals, one of which is to be able to compete with other industries [4].

In general, many industries use the essential criteria of on-time delivery, price, and quality of material offered. Some previous studies have involved standards in determining the selection of suppliers of raw materials, among others: by Dickson [5], there are 23 criteria, Mirmousaa and Dehnavib [6] with 14 criteria and Oktavia and Natalia [7] with 21 criteria.

PT. GMT is engaged in the production of molds and dies. Most of PT GMT customers are industries engaged in manufacturing packaging made from plastic, rubber, and the automotive industry. Mold and dies from PT GMT are mostly used for the manufacture of bottled mineral water, gallons, and reconditioned cup inserts for thermoforming machines, and the production of automotive components. The aim of this study is to select suppliers of 3 types of raw materials, namely aluminum, steel, and end mills.

The customer satisfaction is the most important principle in running a business, so the company sets two main policies, those are delivered goods to consumers on schedule and produce competitive products and high quality. However, there are still shipping customer requests that are not on the delivery schedule. This delay occurs due to one or both of the following two factors. The first factor, suppliers delay the delivery of raw materials. The second one is the quality of raw materials does not meet the required standards, which makes PT GMT must send the raw materials back to the suppliers. Table 1 is the data on delays in the delivery of raw materials during 2018 obtained from interview with the staff of PT GMT:

PT GMT, so far has not have a specific method in selecting suppliers of raw materials. Besides the price of raw materials and transportation costs, PT
GMT requires suppliers that provide best performance from qualitative factors. The performance is determined by the criteria needed including, the method and time of payment, flexibility, order response speed, communication and supplier of raw material reputation, as well as criteria developed based on literature studies. The system used by PT GMT to procure raw materials every month is a multiple sourcing system. This means that the company monthly allocates all of the raw material needs from several different suppliers. The allocation of orders to companies that use multiple sourcing is an important thing to do, because the allocation of orders to several suppliers is to be optimized [8].

Table 1. Data on late delivery of raw materials in 2018

\begin{tabular}{llc}
\hline Due to delay & Frequency & $\begin{array}{c}\text { Average } \\
\text { time } \\
\text { delay }\end{array}$ \\
\hline $\begin{array}{l}\text { Suppliers delay the } \\
\text { delivery of raw materials }\end{array}$ & times & 7 days \\
$\begin{array}{l}\text { Resending of raw } \\
\text { materials due to quality } 2 \text { times } \\
\text { does not meet the } \\
\text { required standards }\end{array}$ & 3 days \\
\hline
\end{tabular}

Many studies discussed of supplier selection based on multi criteria with several Promethee methods. Alfian et al. [9], Mu and Pereyra-Rojas [10], Verma and Pateriya [11], Amini and Asodar [12] used the Analytical Network Process (ANP) method, while Sitio [13], Sodikin et al. [14], Merry et al. [15] used the Analytical Hierarchy Process (AHP) method in selecting material suppliers.

In this study, there are three models mathematics of Linear Program (PL) in selecting suppliers for each raw material. The first PL's objective function to maximize the quality of suppliers who integrate the AHP method with mixed-integer programming called the Total Value of Purchase (TVP). The second objective function is to minimize purchasing costs factor, which is called the Total Cost of Purchase (TCP). Third, with the Goal Programming method based on optimal results from TCP and TVP, this method is used if the supplier selection is based on the two factors in simultaneously. The Optimal solution of each LP will get the allocation of the number of orders 
from each supplier for each type of raw material within the multiple sourcing system.

There are several supplier conditions in previous research on supplier selection discuss the allocation raw material from each supplier, such as all suppliers can supply all raw materials [1], [3], [16], [17]. Other conditions, all suppliers, supply only one type of raw material and only analyze one type of raw material [18], [19]. In this study, analyzing suppliers for each raw material consisting of 3 types of raw materials where 2 suppliers can supply 2 types of raw materials.

\section{RESEARCH METHODS}

Interview and questionnaire instruments were applied to collect the data. The type of data collected in this study are data of the raw materials needed by the company, supplier companies, criteria used by the company, price of raw materials per unit, transportation costs per unit, delivery capacity data from each supplier. The flowchart of this research is shown in Fig.1.

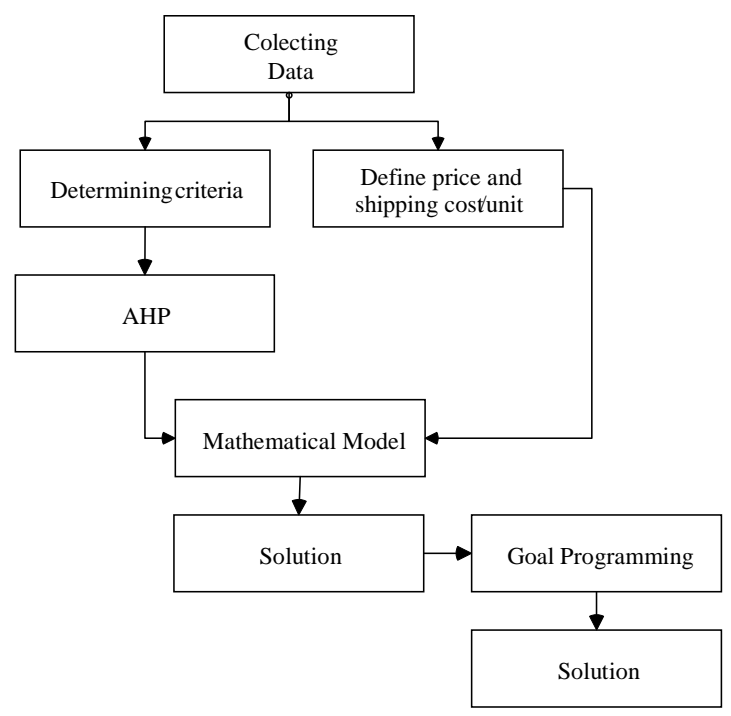

Fig. 1. Flowchart of research methodology

The AHP can be implemented in five consecutive steps:

1. Identifying criteria for selecting suppliers. The company will choose the right criteria based on the company's strategy. The criteria adapted from the literature [3], [6], [8], [14], [20], [21], then distribute to the company for the selection process. The selected criteria and sub criteria are provided in Table 2 .
Table 2. Sub criteria of each criteria

\begin{tabular}{|c|c|c|}
\hline No & Criteria & Sub criteria \\
\hline 1 & Financial & $\begin{array}{l}\text { Price } \\
\text { Payment method } \\
\text { Time of payment }\end{array}$ \\
\hline 2 & Delivery & $\begin{array}{l}\text { Delivery time } \\
\text { On-time delivery }\end{array}$ \\
\hline 3 & Quality & $\begin{array}{l}\text { Incoming quality } \\
\text { Final product quality }\end{array}$ \\
\hline 4 & Service & $\begin{array}{l}\text { Communication skills } \\
\text { Supplier reputation } \\
\text { Order response speed } \\
\text { Flexibility of immediate } \\
\text { Orders }\end{array}$ \\
\hline
\end{tabular}

2. Building decision model hierarchy. The hierarchy consists of criteria and sub-criteria. These sub-criteria are matched with the appropriate criteria.

3. Assessing the priority weights of criteria and supplier priority weights. This step is done using a questionnaire filled out by the purchasing division. The company has 4-5 suppliers for each raw material.

4. Normalizing the priority value data that have been collected.

5. Assessing the consistency of assessment result.

The AHP method is used to obtain the priority weights from each supplier for each raw material. The following are the steps of developing the PL model:

1. Developing the objective Function

There are three objective functions in this study:

a. Objective Function to maximize the quality of suppliers (Total Value of Purchase TVP) This function aims to maximize the quality of supplier. The value of quality is obtained from the priority weight of each supplier for each type of raw material by using the Analytical Hierarchy Process (AHP) method. These priority weights are the coefficients of the objective function called TVP.

b. Objective function to minimize the total cost of purchase (TCP)

This objective function aims to minimize the procurement cost of raw materials, such as the price of raw materials, transportation 
costs for shipping, and other related costs. This function is used because the prices of each supplier are different for each raw material.

c. Goal Programming Method.

The goal programming is applied if the suppliers are selected simultaneously, to minimize the procurement cost of raw materials and maximize the quality of supplier. This method uses optimal results from TVP and TCP. The objective is to minimize the deviation of TVP and TCP. This method uses optimal solution from $T V P_{i}^{o}$ and $T C P_{i}^{o}$. The goal is to minimize deviation from $T V P_{i}^{o}$ and $T C P_{i}^{o}$. The steps of goal programming method are as follows:

1) Develop the constrains:

Develop constrains $\mathrm{TVP}_{\mathrm{i}}$ anda $\mathrm{TCP}_{\mathrm{i}}$

$\sum \mathrm{W}_{\mathrm{ij}} \mathrm{x}_{\mathrm{ij}}+S_{i j}^{+}-S_{i j}^{-} \mathrm{S}_{\mathrm{ij}}=T V P_{i}^{o} ; \forall \mathrm{i}$

$\sum_{j=1}^{N} P_{i j} X_{i j}+\sum_{i=1}^{N} c c_{i j} X_{i j}+S_{i j}^{+}-S_{i j}^{-} \mathrm{S}_{\mathrm{ij}}=T C P_{i}^{o} ; \forall \mathrm{i}$

2) To ensure that the results obtained are as close as possible to the target, the objective function is $\operatorname{Min} \mathrm{S}_{\mathrm{ij}}{ }^{+}+\mathrm{S}_{2}{ }^{-}$.

2. Determine the constrains function

The constrains used in this mathematical model are:

a. The total of raw materials ordered must be equal to or more than the demand of the company, so that the raw material needs of the company can be fulfilled.

b. The total of raw materials ordered must meet the minimum number of orders from suppliers, and may not exceed the maximum orders from the relevant suppliers.

c. Results of raw material orders must be in integers (Integers)

d. The minimum suppliers selected are three suppliers.

To solve this LP by using LINGO 11 software.

\section{RESULTS AND DISCUSSION}

\section{Analytical Hierarchy Process}

The AHP is implemented by building a decisionmaking hierarchy model, consisting of criteria, sub-criteria, and alternative suppliers. The selected criteria in this study are financial, delivery, quality, and service. Then, a comparison of criteria is assessed. This assessment result was obtained by giving the AHP questionnaire (using the Saaty 1-9 scale) to the Head of Purchasing at PT. GMT. Super Decisions software is applied to generate the normalized weights of the criteria, sub-criteria, and weight of suppliers of each raw material. The selected criteria at PT. GMT are financial, shipping, quality, and service.

The results of comparison of criteria using Super Decisions software generated values for financial criteria $=25 \%(0.25)$, delivery $=25 \%(0.25)$, quality $=25 \%(0.25)$ and service $=25 \%(0.25)$. This means that all the criteria have the same important in selecting suppliers at PT. GMT. By using the software, the priority weights for each supplier are also obtained for each raw material (Table 3), the priority weights for each supplier are based on normalized by cluster, and limiting values (Table 4).

Table 3. Comparison of sub criteria

\begin{tabular}{|c|c|c|c|}
\hline Sub criteria & $\begin{array}{l}\text { Normal } \\
\text { ized by }\end{array}$ & Limiting & $\begin{array}{l}\text { Percent } \\
\text { age }(\%)\end{array}$ \\
\hline $\begin{array}{r}2.2 \begin{array}{l}\text { On-time } \\
\text { delivery }\end{array}\end{array}$ & 0.8333 & 0.0694 & $20.83 \%$ \\
\hline $\begin{array}{l}\text { 3.1 Incoming } \\
\text { Quality }\end{array}$ & 0.5000 & 0.0417 & $12.50 \%$ \\
\hline $\begin{array}{ll}2.2 & \text { Final } \\
\text { product } \\
\text { quality }\end{array}$ & 0.5000 & 0.0417 & $12.50 \%$ \\
\hline $\begin{array}{ll}4.3 & \text { Order } \\
& \text { Response } \\
& \text { Speed }\end{array}$ & 0.3679 & 0.0307 & $9.20 \%$ \\
\hline $\begin{array}{l}\text { 4.4 Flexibilit } \\
\text { y of im- } \\
\text { mediate } \\
\text { orders }\end{array}$ & 0.3679 & 0.0307 & $9.20 \%$ \\
\hline 1.1 Price & 0.3333 & 0.0278 & $8.33 \%$ \\
\hline $\begin{array}{l}1.2 \text { Payment } \\
\text { methods }\end{array}$ & 0.3333 & 0.0278 & $8.33 \%$ \\
\hline $\begin{array}{l}1.3 \text { Time of } \\
\text { payment }\end{array}$ & 0.3333 & 0.0278 & $8.33 \%$ \\
\hline $\begin{array}{l}\text { 4.1 Communi } \\
\text { cation } \\
\text { skills }\end{array}$ & 0.1686 & 0.0141 & $4.22 \%$ \\
\hline $\begin{array}{l}\text { 2.1 Delivery } \\
\text { time }\end{array}$ & 0.16667 & 0.0139 & $4.17 \%$ \\
\hline $\begin{array}{ll}\text { 4.2 } & \begin{array}{l}\text { Supplier } \\
\text { reputation }\end{array}\end{array}$ & 0.09557 & 0.0080 & $2.39 \%$ \\
\hline
\end{tabular}


Table 4. Priority weights for suppliers of each raw material

\begin{tabular}{ccccc}
\hline $\begin{array}{c}\text { Type of } \\
\text { raw } \\
\text { material }\end{array}$ & No & Name & $\begin{array}{c}\text { Normalized } \\
\text { by cluster }\end{array}$ & Limiting \\
\hline & 1 & PT W & 0.221 & 0.0737 \\
Aluminum & 2 & PT X & 0.232 & 0.0775 \\
& 3 & PT Y & 0.274 & 0.0915 \\
& 4 & PT Z & 0.272 & 0.0906 \\
\hline & 1 & PT Z & 0.230 & 0.0767 \\
& 2 & PT Y & 0.228 & 0.0759 \\
Steel & 3 & PT C & 0.195 & 0.0650 \\
& 4 & PT D & 0.189 & 0.0632 \\
& 5 & PT E & 0.158 & 0.0527 \\
\hline & 1 & PT H & 0.259 & 0.0863 \\
End Mill & 2 & PT I & 0.295 & 0.0985 \\
& 3 & PT J & 0.158 & 0.0527 \\
& 4 & PT K & 0.288 & 0.0959 \\
\hline
\end{tabular}

\section{Formation of Mathematical Models}

Defining decision variables and parameters, for the formation of mathematical models of LP.

1. Defining Variables

Let :

$\mathrm{x}_{\mathrm{ij}}$ : the number of raw materials $\mathrm{i}$ will be supplied from supplier $\mathrm{j}$,

$\mathrm{x}_{\mathrm{ij}}$ is an integer variable.

$\mathrm{y}_{\mathrm{ij}}$ is a binary variable, selection the suppliers,

$y_{i j}=\left\{\begin{array}{l}1, \text { if supplier } j \text { is selected }\left(\mathrm{x}_{\mathrm{ij}}>0\right) \\ 0, \quad \text { for others }\end{array}\right.$

$\mathrm{y}_{\mathrm{ij}} \varepsilon(0,1)$

2. Defining Parameter

Let:

$\mathrm{N}$ : Number of competing suppliers

$\mathrm{W}_{\mathrm{ij}}$ : AHP final weight of $j$ th supplier for $i$ th raw material.

$\mathrm{V}_{\mathrm{ij}}$ : Minimum number of $i$ th raw material from $j$ th supplier

$\mathrm{C}_{\mathrm{ij}}$ : Maximum capacity of $j$ th supplier for $i$ th raw material

$\mathrm{D}_{\mathrm{i}}$ : Total $i$ th raw material requirements at planning period

$\mathrm{P}_{\mathrm{ij}} \quad$ : Price of $i$ th raw material per unit from $j$ th supplier

$\mathrm{cc}_{\mathrm{ij}}$ : Transportation/shipping costs $i$ th raw material/unit from $j$ th supplier

$\mathrm{n}_{\min }:$ Minimum number of suppliers selected $\mathrm{n}_{\max }:$ Maximum number of suppliers selected

3. General Mathematical Model

There are three LP models for supplier selection, whose objective function is: based on minimizing the procurement cost of raw materials, based on the maximum quality of supplier, and based on both simultaneously. According to Kokangul and Susuz [3], the general mathematical models are:

Objective Function:

$\operatorname{Max}\left(T V P_{i}\right)=\sum_{j=1}^{N} W_{i j} X_{i j}$

$\operatorname{Min}\left(T C P_{i}\right)=\sum_{j=1}^{N} P_{i j} X_{i j}+\sum_{i=1}^{N} c c_{i j} X_{i j}$

Subject to :

$\sum_{j=1}^{N} x_{i j}=D_{i}$

$\mathrm{x}_{\mathrm{ij}} \geq \mathrm{V}_{\mathrm{ij}} \forall \mathrm{i}$

$y_{i j}=\left\{\begin{array}{l}1, x_{i j}>0 \\ 0, \text { other }\end{array}, \forall i\right.$

$n_{\min } \leq \sum_{j=1}^{N} Y_{i j} \leq n_{\max }$

$x_{i j} \leq C_{i j}, \forall i$

$x_{i j}$ : integer, $\forall i$ and $\forall j$

$\mathrm{y}_{\mathrm{ijj}} \varepsilon(0,1), \forall i$ and $\forall j$

Equation (1) for the objective function of selecting suppliers based on the maximum quality of supplier, while equation (2) for minimum procurement cost.

4. Mathematical models based on maximum supplier quality $\left(\mathrm{TVP}_{\mathrm{i}}\right)$.

The objective function of each raw material uses equation (1), while the constrains function uses equations (3), (5), ..., (9). In this case, equation (4) is not used because there is no minimum order for each raw material. The following mathematical models for each raw material.

a. For Aluminum Suppliers $(i=1)$

In this case there are 4 competing suppliers, so $\mathrm{j}=1, \ldots, 4$, where $\mathrm{j}=1$ for PT $\mathrm{W}, \mathrm{j}=2$ for PT $X, j=3$ for PT $Y$ and $j=4$ for PT Z. The mathematics model are as follows:

Objective Function:

Max: $\mathrm{TVP}_{1}=0.221 \mathrm{x}_{11}+0.233 \mathrm{x}_{12}+0.274 \mathrm{x}_{13}+0.272 \mathrm{x}_{14}$

Subject to:

$\mathrm{x}_{11}+\mathrm{x}_{12}+\mathrm{x}_{13}+\mathrm{x}_{14}=150$

$\mathrm{x}_{1 \mathrm{j}}<=60 ; \forall \mathrm{j}=1, \ldots 4$

$y_{i j}=\left\{\begin{array}{l}1, \mathrm{X}_{\mathrm{ij}}>0 \\ 0, \text { other }\end{array}, \forall i\right.$

$\sum_{j=1}^{4} y_{1 j} \geq 3$

$\mathrm{x}_{1 \mathrm{j}}$ : integers, $\forall j$

$\mathrm{y}_{1 \mathrm{j}}: \varepsilon(0,1), \forall j$ 
b. For Steel Suppliers $(i=2)$

There are 5 suppliers, so $\mathrm{j}=1, \ldots, 5$, where $\mathrm{j}=$ 1 for PT Z, j = 2 for PT Y, j = 3 for PT C, j = 4 for PT D and $\mathrm{j}=5$ for PT E. The LP is:

Objective Function:

Max: $\mathrm{TVP}_{2}=0.230 \mathrm{x}_{21}+0.228 \mathrm{x}_{22}+0.195 \mathrm{x}_{23}+0.189 \mathrm{x}_{24}$ $+0.158 \mathrm{x}_{25}$

Subject to :

$$
\begin{aligned}
& \mathrm{x}_{21}+\mathrm{x}_{22}+\mathrm{x}_{23}+\mathrm{x}_{24}+\mathrm{x}_{25}=200 \\
& \mathrm{x}_{2 \mathrm{j}} \leq 60 ; \forall \mathrm{j}=1, \ldots .5 \\
& y_{i j}=\left\{\begin{array}{l}
1, x_{i j}>0 \\
0, \text { Other }
\end{array}, \forall i\right. \\
& \sum_{j=1}^{5} y_{2 j} \geq 4 \\
& \mathrm{x}_{2 j} \text { integers, } \forall j \\
& \mathrm{y}_{2 \mathrm{j}} \varepsilon(0,1), \forall j
\end{aligned}
$$

c. For End Mill Suppliers (i = 3)

In this case there are 4 suppliers, so $\mathrm{j}=1, \ldots, 4$, where $\mathrm{j}=1$ for PT $\mathrm{H}, \mathrm{j}=2$ for PT I, $\mathrm{j}=3$ for PT $J$ and $j=4$ for PT K. The LP is:

Objective Function:

Max: $\mathrm{TVP}_{3}=0.259 \times 31+0.295 \times 32+0.158 \times 33$ $+0.288 \times 34$

Subject to :

$$
\begin{aligned}
& \mathrm{x}_{31}+\mathrm{x}_{32}+\mathrm{x}_{33}+\mathrm{x}_{34}=50 \\
& \mathrm{x}_{3 \mathrm{j}} \leq 30 ; \forall \mathrm{j}=1, \ldots 4 \\
& y_{i j}=\left\{\begin{array}{l}
1, X_{i}>0 \\
0, \text { Other }
\end{array}, \forall i\right. \\
& \sum_{j=1}^{4} y_{2 j} \geq 3 ; \\
& \mathrm{x}_{3 j}: \text { integers, } \forall j \\
& \mathrm{y}_{3 \mathrm{j}} \varepsilon(0,1), \forall j
\end{aligned}
$$

5. A mathematical model based on minimum procurement cost $(\mathrm{TCPi})$

For the same raw materials, the constrains equal with the constrains on the maximum quality of supplier.

a. For Aluminum Suppliers $(i=1)$

The LP is :

Objective Function:

Max: $\mathrm{TCP}_{1}=72220 \mathrm{x}_{11}+59800 \mathrm{x}_{12}+101200 \mathrm{x}_{13}$

$$
+119600 \times 14+6280 \times 11+5200 \times 12
$$$$
+8800 \mathrm{x}_{13}+10400 \mathrm{x}_{14}
$$

Subject to :

Equations (9) to (12)

$\mathrm{x}_{1 j}$ : integers, $\forall j$

$\mathrm{y}_{1 \mathrm{j}} \varepsilon(0,1), \forall j$

b. For Steel Suppliers $(\mathrm{i}=2)$

The LP is :

Objective Function:

Max: $\mathrm{TCP}_{2}=87400 \mathrm{x}_{21}+95220 \mathrm{x}_{22}+79120 \mathrm{x}_{23}+73600 \mathrm{x}_{24}$

$$
\begin{aligned}
& +93380 \mathrm{x}_{25}+7600 \mathrm{x}_{21}+8280 \mathrm{x}_{22}+6880 \mathrm{x}_{23} \\
& +6400 \mathrm{x}_{24}+8120 \mathrm{x}_{25}
\end{aligned}
$$

Subject to :

Equations (14) to (17) $\mathrm{x}_{2 j}$ : integers, $\forall j$

$\mathrm{y}_{2 \mathrm{j}} \varepsilon(0,1), \forall j$

c. For End Mill Suppliers (i = 3)

The LP is "

Objective Function:

Max: $\mathrm{TCP}_{3}=33250 \mathrm{x}_{31}+33250 \mathrm{x}_{32}+45600 \mathrm{x}_{33}+38950 \mathrm{x}_{34}$ $+1750 \mathrm{x}_{31}+1750 \mathrm{x}_{32}+2400 \mathrm{x}_{33}+2050 \mathrm{x}_{34}$

Subject to :

Equations (19) to (22)

$\mathrm{x}_{3 j}$ : integers, $\forall j$

$\mathrm{y}_{3 \mathrm{j}} \varepsilon(0,1), \forall j$

6. Goal Programming Method

This method is used if the supplier selection is based on both the maximum quality of supplier and the minimum procurement cost of raw material simultaneously. This model was developed after we get the optimal solution from $\mathrm{TCP}_{\mathrm{i}}$ and $\mathrm{TVP}_{\mathrm{i}}$. Let :

$S_{i k}^{+}$is the deviation variable positive of $i$ th raw material for $k$ th constraint.

$S_{i k}^{-}$is the deviation variable negative of $i$ th raw material for $k$ th constraint. ; $\forall \mathrm{i}=1,2,3$ and $\mathrm{k}=1,2 ; \mathrm{k}=1$ for objective function TVP and $\mathrm{k}$ $=2$ for objective function TCP.

a. For Aluminum Suppliers ( $\mathrm{i}=1)$

From LINGO software, the optimal solution of $\mathrm{TCP}_{1}$ is $T V P_{1}^{o}=11910000$, and $\mathrm{TVP}_{1}$ is $T V P_{1}^{o}=$ 39.75. The LP is :

Objective Function:

Max: $\mathrm{Z}_{1}=S_{11}^{+}+S_{12}^{-}$

Subject to :

Equation (9) through equation (12)

$\mathrm{x}_{12}+101200 \mathrm{x}_{13}+119600 \mathrm{x}_{14}+6280 \mathrm{x}_{11}+5200 \mathrm{x}_{12}$

$+8800 \mathrm{x}_{13}+10400 \mathrm{x}_{14}+S_{12}^{+}-S_{12}^{-}=11910000$

$\mathrm{x}_{1 j}$ : integers, $\forall j$

$\mathrm{y}_{1 j}, \varepsilon(0,1), \forall j$

b. For Steel Suppliers $(i=2)$

From LINGO software solution, the optimal solution of $\mathrm{TCP}_{2}$ is $T C P_{2}^{o}=17690000$ and $\mathrm{TVP}_{2}$ is $T V P_{2}^{o}=42.95$.

Objective Function:

Max: $\mathrm{Z}_{1}=S_{21}^{+}+S_{22}^{-}$

Subject to :

Equations (14) to (17)

$0.230 \mathrm{x}_{21}+0.228 \mathrm{x}_{22}+0.195 \mathrm{x}_{23}+0.189 \mathrm{x}_{24}+0.158 \mathrm{x}_{25}$

$+S_{21}^{+}-S_{21}^{-}=42.95$

$87400 \mathrm{x}_{21}+95220 \mathrm{x}_{22}+79120 \mathrm{x}_{23}+73600 \mathrm{x}_{24}+93380 \mathrm{x}_{25}$

$+7600 \mathrm{x}_{21}+8280 \mathrm{x}_{22}+6880 \mathrm{x}_{23}+6400 \mathrm{x}_{24}+8120 \mathrm{x}_{25}+S_{22}^{+}$

$-S_{22}^{-}=17690000$

$\mathrm{x}_{2 j}$ : integers, $\forall i$

$\mathrm{y}_{2 \mathrm{j}} \varepsilon(0,1), \forall j$ 
c. For End Mill Suppliers ( $\mathrm{i}=3$ )

From LINGO software solution. the optimal TCP 3 results are $T C P_{3}^{o}=1756000$ and $\mathrm{TVP}_{3}$ is $T V P_{3}^{o}=14.55$

Objective Function:

Max: $Z_{1}=S_{31}^{+}+S_{32}^{-}$

Subject to :

Equation (19) to Equation (22)

$0.259 \mathrm{x}_{31}+0.295 \mathrm{x}_{32}+0.158 \mathrm{x}_{33}+0.288 \mathrm{x}_{34}+S_{31}^{+}$

$-S_{31}^{-}=14.55$

$33250 \mathrm{x}_{31}+33250 \mathrm{x}_{32}+45600 \mathrm{x}_{33}+38950 \mathrm{x}_{34}+1750 \mathrm{x}_{31}$

$+1750 \mathrm{x}_{32}+2400 \mathrm{x}_{33}+2050 \mathrm{x}_{34}+S_{32}^{+}-S_{32}^{-}=1756000$

$\mathrm{x}_{3 j}$ : integers, $\forall j$

$\mathrm{y}_{3 \mathrm{j}} \varepsilon(0,1), \forall j$

\section{Results of Processing Mathematical Models and Analysis}

Solving the LP models by using LINGO 11 software. The optimal supplier of aluminum material based on the maximum quality of supplier or maximum value (maximum priority weight value or Maximum TVP) is 39.75 . The procurement cost is IDR 16,350,000. The suppliers are PT X, Y, and Z, with respectively supplies: $30 \mathrm{~kg}, 60 \mathrm{~kg}$, and $60 \mathrm{~kg}$. If the supplier selection to minimize the procurement cost of raw material (Minimum TCP), the procurement cost are $\mathrm{Rp} 11,910,000$, with a value of 35.46. The suppliers are PT W, PT X, and PT Y with respectively supplies: $60 \mathrm{~kg}, 60 \mathrm{~kg}$, and $30 \mathrm{~kg}$. Meanwhile, if the supplier selection is based on Goal Programming, the suppliers are PT W, PT X, and PT Y Z with respectively supplies: $33 \mathrm{~kg}, 60$ $\mathrm{kg}$, and $57 \mathrm{~kg}$ (Table 5).

Selection suppliers of steel based on the quality of supplier, the suppliers are PT Z, PT Y, PT C, and PT D with respectively supplies: $60 \mathrm{~kg}, 60 \mathrm{~kg}, 60$ $\mathrm{kg}$, and 20 with a value of 42.95 and the procurement cost is $\mathrm{Rp} 18.670,000$. If the selection is based on a minimum cost, the suppliers are PT Z, PT C, PT D, and PT E with respectively supplies: $60 \mathrm{~kg}, 60 \mathrm{~kg}, 60 \mathrm{~kg}$, and 20 $\mathrm{kg}$ with a value of 40.02 and costs Rp. 17,690,000. Meanwhile, if based on Goal Programming, the suppliers are PT Z, PT Y, PT C, and PT D with respectively supplies: $60 \mathrm{~kg}, 39 \mathrm{~kg}, 42 \mathrm{~kg}$, and 59 $\mathrm{kg}$ with a value of 42.95 and the cost is $\mathrm{Rp}$. 18,670,000 (Table 6).

End mill raw material suppliers based on the quality of supplier, the minimum procurement cost and based Goal Programming are same, namely: PT H, PT I, and PT K, the difference is the amount of supply. Based on the quality of suppliers, the number of supply respectively is 1 $\mathrm{kg}, 25 \mathrm{~kg}$, and $24 \mathrm{~kg}$ in with the value is 14.55 , and the procurement cost is $\mathrm{Rp} 1,894,000$. Based on the minimum procurement cost, the number of supply respectively is: $30 \mathrm{~kg}, 19 \mathrm{~kg}$ and $1 \mathrm{~kg}$ with the value is 13.66 and the procurement cost is $\mathrm{Rp}$. $1,756,000$. Meanwhile, if the selection of suppliers by considering both, the number of supply respectively is: $13 \mathrm{~kg}, 30 \mathrm{~kg}$ and $7 \mathrm{~kg}$ with a value of 14.24 and costs Rp. 1,792,000 (Table 7).

Table 5. Results of mathematical model processing for aluminum

\begin{tabular}{ccccccc}
\hline \multirow{2}{*}{ Objective Function } & \multicolumn{9}{c}{ Variables (suppliers) } & & \multirow{2}{*}{ Cost } \\
& $\mathbf{x}_{\mathbf{1 1}}$ & $\mathbf{x}_{\mathbf{1 2}}$ & $\mathbf{x}_{\mathbf{1 3}}$ & $\mathbf{x}_{\mathbf{1 4}}$ & Value & $(\mathbf{R p )}$ \\
\hline Max TVP $_{1}$ & 0 & $\mathbf{X}$ & $\mathbf{Y}$ & $\mathbf{Z}$ & & $16,350,000$ \\
Min TCP $_{1}$ & 60 & 60 & 60 & 60 & 39.75 & $11,910,000$ \\
Goal Programming & 33 & 60 & 57 & 0 & 35.46 & $12,760,500$ \\
\hline
\end{tabular}

Table 6. Results of processing mathematical models for steel

\begin{tabular}{|c|c|c|c|c|c|c|c|}
\hline \multirow[b]{2}{*}{ Objective Function } & \multicolumn{5}{|c|}{ Variables (suppliers) } & \multirow[b]{2}{*}{ Value } & \multirow[b]{2}{*}{$\begin{array}{l}\text { Cost } \\
\text { (Rp) }\end{array}$} \\
\hline & $\begin{array}{c}\mathbf{x}_{11} \\
\mathbf{Z} \\
\end{array}$ & $\begin{array}{c}\mathbf{x}_{12} \\
\mathbf{Y} \\
\end{array}$ & $\begin{array}{c}\mathbf{x}_{13} \\
\mathbf{C} \\
\end{array}$ & $\begin{array}{c}\mathbf{X}_{14} \\
\mathrm{D} \\
\end{array}$ & $\begin{array}{c}\mathbf{x}_{15} \\
\mathbf{E} \\
\end{array}$ & & \\
\hline $\mathrm{Max}_{\mathrm{TVP}}$ & 60 & 60 & 60 & 20 & 0 & 42.95 & $18,670,000$ \\
\hline $\operatorname{Min} \mathrm{TCP}_{2}$ & 60 & 0 & 60 & 60 & 20 & 40.02 & $17,690,000$ \\
\hline Goal Programming & 60 & 39 & 42 & 59 & 0 & 42.05 & $18,068,500$ \\
\hline
\end{tabular}


Table 7. Results of mathematical model processing for end mill

\begin{tabular}{|c|c|c|c|c|c|c|}
\hline \multirow[b]{2}{*}{ Objective Function } & \multicolumn{4}{|c|}{ Variable (supplier) } & \multirow[b]{2}{*}{ Value } & \multirow[b]{2}{*}{$\begin{array}{l}\text { Cost } \\
(\mathbf{R p})\end{array}$} \\
\hline & $\begin{array}{c}\mathbf{x}_{11} \\
\mathbf{H} \\
\end{array}$ & $\begin{array}{c}\mathbf{x}_{12} \\
\mathbf{I} \\
\end{array}$ & $\begin{array}{c}\mathbf{x}_{13} \\
\mathbf{J}\end{array}$ & $\begin{array}{c}\mathbf{x}_{14} \\
\mathbf{K} \\
\end{array}$ & & \\
\hline $\mathrm{Max} \mathrm{TVP}_{3}$ & 1 & 25 & 0 & 24 & 14.55 & $1,894,000$ \\
\hline $\operatorname{Min} \mathrm{TCP}_{3}$ & 30 & 19 & 0 & 1 & 13.66 & $1,756,000$ \\
\hline Goal Programming & 13 & 30 & 0 & 7 & 14.24 & $1,792,000$ \\
\hline
\end{tabular}

Procurement cost have the highest value for all raw materials if the supplier selection based on the maximum quality of supplier. The lowest value of the quality of supplier for all raw materials occurs if the supplier selection based on the minimum procurement cost. Meanwhile, if the supplier selection based on the quality of supplier and the least procuring cost of raw materials simultaneously. The Value quality of supplier and the procurement cost are between the both.

This method have minimized the number of the suppliers of raw materials by eliminating several suppliers according to the company's policy. Example for Aluminum raw material, if supplier selection is based on the quality of supplier, PT X suppliers are eliminated, while if based on the minimum procurement cost, supplier $\mathrm{Z}$ is eliminated. For end mill raw materials, PT J suppliers are eliminated for all-Objective Functions. This shows that PT J cannot compete with other suppliers. So that in the future, PT J will no longer be included as a supplier. The results of this study indicate that this method can be applied to the mold and dies industry.

\section{CONCLUSION}

Based on the data processing, the conclusion that the selection of suppliers based on the quality of supplier, minimum procurement costs and Goal Programming method, the total value respectively is $97.25,89.14$, and 93.18 and the procurement cost respectively is $\mathrm{Rp} 36,914,000, \mathrm{Rp} 31,356,000$ and $\operatorname{Rp} 32,621,000$. The optimal value of the quality of supplier and the procurement cost of the Goal Programming method is between the optimal TCP and TVP values for each raw material. So PT GMT has been able to determine the optimal supplier based on the policies set. PT Y and PT Z supply Aluminum and Steel. For End Mill raw material suppliers, PT J cannot compete with other suppliers, so PT GMT must find a new supplier. Future studies can minimize subjectivity by adding respondents to fill out questionnaires or adding criteria using quantitative data. Making a new mathematical model that considers more complex constraints, for example, considering: the discount factor for purchasing raw materials, the company's budget, so that the total purchase cost does not exceed the budget. It is necessary to develop a mathematical model for suppliers who can supplies more than one raw material by budget restrictions or the quantity restrictions.

\section{REFERENCES}

[1] E. Mehdizadeh and M. Ayobi, "A fuzzy multi objective model for supplier selection," in Proceedings of the 2nd International Conference on Manufacturing Engineering, Quality and Production Systems, 2007, vol. 18, pp. 241-252, available at: http://www.wseas.us/elibrary/conferences/2010/Constantza/ME QAPS/MEQAPS-43.pdf.

[2] F. Lemke, K. Goffin, and M. Szwejczewski, "Investigating the meaning of supplier-manufacturer partnerships," Int. J. Phys. Distrib. Logist. Manag., vol. 33, no. 1, pp. 12-35, Feb. 2003, doi: 10.1108/09600030310460981.

[3] A. Kokangul and Z. Susuz, "Integrated analytical hierarch process and mathematical programming to supplier selection problem with quantity discount," Appl. Math. Model., vol. 33, no. 3, pp. 1417-1429, Mar. 2009, doi: 10.1016/j.apm.2008.01.021.

[4] K. Mukherjee, Supplier selection: An MCDA-based approach, vol. 88. New Delhi: Springer India, 2017, doi: 10.1007/978-81-322-3700-6. 
[5] G. W. Dickson, "An Analysis Of Vendor Selection Systems And Decisions," $J$. Purch., vol. 2, no. 1, pp. 5-17, Feb. 1966, doi:10.1111/j.1745-493X.1966.tb00818.x.

[6] S. Mirmousa and H. D. Dehnavi, "Development of Criteria of Selecting the Supplier by Using the Fuzzy DEMATEL Method," Procedia - Soc. Behav. Sci., vol. 230, pp. 281-289, Sep. 2016, doi: 10.1016/j.sbspro.2016.09.036.

[7] C. W. Oktavia, C. Nathalia, and S. G. Tjhong, "Pendekatan Metode Interpretive Structural Modeling dalam Penentuan Kriteria Kunci Pemilihan Supplier Pada Perusahaan Konstruksi," J. TIARSIE, vol. 16, no. 3, p. 100, Sep. 2019, doi: 10.32816/tiarsie.v16i3.56.

[8] K. Mukherjee, "Supplier selection criteria and methods: past, present and future," Int. J. Oper. Res., vol. 27, no. 2, pp. 356-373, 2016, doi: 10.1504/IJOR.2016.078470.

[9] I. A. Sandy and H. Fathurahman, "Penggunaan Metode Analytic Network Process (ANP) dalam Pemilihan Supplier Bahan Baku Kertas pada PT Mangle Panglipur," J. Rekayasa Sist. Ind., vol. 2, no. 1, pp. 32-39, 2013, available at: http://journal.unpar.ac.id/index.php/jrsi/ar ticle/view/334.

[10] E. Mu and M. Pereyra-Rojas, Practical Decision Making using Super Decisions v3. Cham: Springer International Publishing, 2018, doi: 10.1007/978-3-31968369-0.

[11] D. S. Verma and A. Pateriya, "Supplier selection through analytical hierarchy process: A case study in small scale manufacturing organization," Int. J. Eng. trends Technol., vol. 4, no. 5, pp. 14281433, 2013, available at: https://ijettjournal.org/archive/ijettv4i5p23.

[12] S. Amini and M. A. Asoodar, "Selecting the most appropriate tractor using Analytic Hierarchy Process - An Iranian case study," Inf. Process. Agric., vol. 3, no. 4, pp. 223-234, Dec. 2016, doi: 10.1016/j.inpa.2016.08.003.

[13] A. S. Sitio, "Sistem Pendukung Keputusan
Penentuan Supplier Pembelian Barang Menggunakan Metode Analytical Hierarchy Process pada PT. Perintis Sarana Pancing Indonesia," J. Inform. Pelita Nusant., vol. 2, no. 1, pp. 40-47, 2017, available at: http://ejurnal.pelitanusantara.ac.id/index.php/JIP N/article/view/297.

[14] I. Sodikin, C. I. Parwati, and B. Oktarando, "Identifikasi Profil dan Penentuan Preferensi Konsumen Restoran Fast Food Lokal di Yogyakarta," in Prosiding Industrial Engineering National Conference (IENACO), 2015, available at: https://publikasiilmiah.ums.ac.id/xmlui/ha ndle/11617/5944.

[15] L. Merry, M. Ginting, and B. Marpaung, "Pemilihan supplier buah dengan pendekatan metode Analytical Hierarchy Process (AHP) dan TOPSIS: Studi kasus pada perusahaan retail," J. Tek. dan Ilmu Komput., vol. 3, no. 9, pp. 48-58, 2014, available at: http://ejournal.ukrida.ac.id/ojs/index.php/J TIK/article/view/831.

[16] S. A. Darestani, S. Ghavami, and A. Azizi, "Supply Chain Management: Supplier Selection Problem with multi-objective Considering Incremental Discount," Asia Pacific Ind. Eng. Manag. Syst., vol. 14, no. 1, pp. 1-9, 2013, available at: http://umpir.ump.edu.my/6021/1/fkpAmir-Asia_Pacific_IE,_2013.pdf.

[17] J. Razmi and H. Rafiei, "An integrated analytic network process with mixedinteger non-linear programming to supplier selection and order allocation," Int. J. Adv. Manuf. Technol., vol. 49, no. 912, pp. 1195-1208, Aug. 2010, doi: 10.1007/s00170-009-2445-5.

[18] A. Mendoza and J. A. Ventura, "Analytical models for supplier selection and order quantity allocation," Appl. Math. Model., vol. 36, no. 8, pp. 3826-3835, Aug. 2012, doi: 10.1016/j.apm.2011.11.025.

[19] J. Wang, R. Zhao, and W. Tang, "Fuzzy programming models for vendor selection problem in a supply chain," Tsinghua Sci. Technol., vol. 13, no. 1, pp. 106-111, Feb. 2008, doi: $\quad 10.1016 /$ S1007- 
0214(08)70017-8.

[20] H. Taherdoost, "Decision Making Using the Analytic Hierarchy Process (AHP); A Step by Step Approach," vol. 2, pp. 244246, 2017, available at: https://papers.ssrn.com/sol3/papers.cfm?a bstract_id=3224206.

[21] Ž. Stević, "Criteria for supplier selection: A literature review," Int. J. Eng. Bus. Enterp. Appl., vol. 19, no. 1, pp. 23-27, 2017, available at: http://iasir.net/ijebeaissue/ijebeaissue191.html. 